\title{
View on Educational Thoughts in Old Testament
}

\author{
Juntao Zhao \\ Physical Education College \\ Zhengzhou University \\ Zhengzhou, China \\ e-mail: maodoubaby@126.com
}

\begin{abstract}
The ancient Jewish people attach great importance to education. In their classic Old Testament, there are many important educational thoughts which have an important inspiration for future generations. The author has sorted out some education thoughts of ancient Jewish people through reading Old Testament to give inspiration to people.
\end{abstract}

Keywords —old testament; education; thoughts

\section{INTRODUCTION}

The ancient Jewish people have passed down only one cultural classic Old Testament to future generations. To study their education thoughts, we have to start from Old Testament. In the Old Testament, the discussion on educational thoughts is mainly included in wisdom literature, such as Proverbs and Ecclesiastes. The Jewish people have very special religious idea, so their education also is given with a very strong color of theology. It results that most of their education contents are about their ethic religious knowledge, such as to know God. The paper has studied their educational thoughts from this aspect in order to provide us with a panoramic overview of ancient Jewish Education concepts and provide a reference for our modern education.

In ancient Jewish literature, there are some synonyms and near-synonyms for education, such as "musar", "instruction", "indoctrination" and "lessons". In Septuagint Version, it was translated as "paideia" in Greek. According to statistics, the word "paideia" appears 36 times in Ecclesiastes and 5 times in Wisdom of Solomon. The word "musar" appears 30 times in proverbs, 8 times in Jeremiah and 5 times in Job. The Hebrew word "musar" is often associated with wisdom. [1]305 The other word or word root related to education or lesson is "lmd" whose meaning is "learning or education". This word mainly appears in Deuteronomy, Isaiah, Jeremiah and Psalm. Another educational-related word root is "yrh" which mainly appears in Genesis and Exodus. The meaning in noun form is education and teacher. According to statistics, the word "writing" has appeared only one time in Homer's Epic Iliad and not even once in Odyssey, but it has appeared 429 times in Old Testament. It again proves that Jewish people take education and learning seriously.

\section{EDUCATION INSTITUTION OF ANCIENT JEWISH PEOPLE}

Jewish children receive enlightenment education at home at first. They learn religious knowledge, moral principles, living skills and their traditional culture from home education. Therefore, home has become a veritable education institution in ancient Jewish society. In fact, the scholar's study has showed that at home not only parents educate their children but also other family members, such as grandparents, uncles and cousins. [1]307 In the Jewish history of education, the education institution Jewish Home has played a decisive role.

In the Jewish history of education, Jewish Synagogue and annual religious rites in the temple also play very important role in education. Every year children following their parents go to the temple to worship God. As the establishment of Jerusalem Temple, they go to Jerusalem Temple to worship God every year. In the temple, they hold a lot of religious rites especially in religious festivals, which is a good opportunity to educate children. In these rites, children repeat listening to bible scriptures and gradually remain them in their mind. In Deuteronomy (31:12), it provides that "Gather the people together, men, and women, and children, and the stranger that is within the gates, that they may hear, and that they may learn, and fear the LORD your God, and observe to do all the words of this law". What's more, they sometimes repeatedly sing bible scriptures, especially psalms with national tradition and moral principles. In this way, children learn a lot of knowledge about their national traditional history. More importantly than all of that, they learn to fear God and know God. Except for the annual worship in the temple, Jewish also hold other religious rites every year in their religious festivals which is also a good opportunity to educate their children. For example, in the Passover, they tell their children to keep the story in mind that God saved their ancestors from the slavery of Egyptians. In the festival, the priest will take some firstfruit and shake them before Yahweh. Before this, the Israelite may select a wheat field, pick out the best and bundle a bundle of wheat. To the next day in the evening, three men to harvest in the field while a lot of people are watching the rite, including children. The reapers will ask a few of traditional questions. At this time, children in the rite listen to the questions and answers. Year after year, they not only learn a lot of knowledge about national traditional history but also a lot of religious 
knowledge. The other festivals, such as Pentecost and Sukkot, are similar. In the social festival, children obtain a lot of social knowledge, which is equivalent to receiving social education.

In ancient Jewish society, the key education insinuation is still the school. According to studies, the Jewish school has existed as early as the period of Monarchy in the Israel. [1]308 At that time, schools were very simple. It could be called as school as long as there was only one learnt teacher with a group of student sitting around him in a place. This kind of school is different with school in modern sense. Before King David and Solomon, there is no obvious school but some education institutions similar to school. Samuel learned religious knowledge with Eli in Shiloh in his childhood. He might receive education in a similar school institution with the sons of Eli (Samuel 2/12; 3/1). To the periods under the reign of David and Solomon, Jewish society appeared school - royal school or noble school which are mainly for children of the nobility and royal family, and distributed in the kingdom capitals in Shechem and Samaria. The Bible clearly documented under the reign of Ahab of Israel his seventy sons received education in a royal school in Samaria (Kings II 10). After the establishment of Jerusalem Temple, the priest school appeared for the purpose of training qualified clergies - priests for the service in the temple. In the priest school, educatees learned reading, writing, singing, music, festivals, calendar and the national traditional knowledge under supervision of Great Priest, so that they could do the work of the temple. In general, the school conditions are relatively good due to the special Jewish religious background. Probably at that time, there existed library in the priest school (Kings II 22:8). Sometimes, the priest school also accepted royal children and was responsible for their education. As the existence of the prophet class, the prophets established a specialized school - prophet school. At the start, some prophets might receive education in royal school (such as Isaiah and Zephaniah) or priest school (such as Ezekiel, Jeremiah and Malachi), but prophets had their own disciples and schools. Kings II recorded Elijah had more that 50 disciples (2:7) resulting that the school couldn't hold and they had to go out into wilderness for lectures $(6: 1 \sim 2)$. In $586 \mathrm{BC}$, the Jews were exiled. In the later Hellenistic period, due to the impact of foreign culture, Jewish society got very great impact as well as education. Since then, Jewish education, on one aspect, passed on the national traditional knowledge to maintain national consciousness and national dignity, and on the other aspect, started absorbing foreign factors to further improve their education system. According to records, in the 3rd Century BC, some Jewish synagogues started to set up school of modern type. In the 2nd Century, the school started to separate from synagogue.

\section{ANCIENT JEWISH EDUCATORS}

In ancient Jewish society, the first enlightenment teachers of children were parents who were the first teachers of children. Children first received elementary education at home. They learned to pray and sing psalm, and learned religious knowledge, such as to know God, moral principles and certain skills. Old Testament, more than once, recorded, "My son, hear the instruction of your father, and forsake not the law of your mother" (Proverbs 1:8). In general, it is father who is responsible for teaching the son and mother who assists father. However, mother also takes main responsibility to educate their children in their early childhood. This Jewish tradition has a far-reaching influence. "Even up to the Talmudic Period, it was still parents' responsibilities to teach laws and living skills and find wives for their sons". [2]401 This good tradition help Jewish from their childhood develop a virtue of respecting their parents. In ancient Jewish society, Jewish children received education from their parents as teachers, except for royal children (Kings II 10:1). Old Testament records it vaguely and does not specify it. Therefore, in Hebrew "father" has the meaning of "teacher". In modern English, "father" refers to dad and godfather. It follows the Hebrew word culture.

Starting from the period of Moses, the priest took on the duty of teacher. They were Jewish clergies, so they taught people knowledge about their religion and educated the public with God's laws to avoid people going against the will of God and incurring punishment. Torah clearly stipulates that priests can not own land, so they can not support themselves and get the support from Israelites. Torah also expressly provides that Israel shall give certain part of their offer for God to priests. In fact, it is a euphemistic reward to priests. As workers of synagogue, Levi also took the duty of teachers (Deuteronomy 33:10) and their duty was similar to that of priests. They mainly taught people the laws of the religious theology and taught the public to fear God.

Before captivity, in ancient Jewish society rose a group of scholars - prophets. They in certain extent took the duty of teacher in this period. Their duty mainly was to expound laws to people at that time and taught the public ancestors' historic lessons. At same time, they took the responsibility to criticize royal wealth, social corruption and injustice. On behalf of God, they appeared as prophets. They warned the reality, predicted the future, pointed out sins, called for repentance, predicted the birth of the redeemer and guided people to the righteousness". [3]17 In addition, as God's spokesman, "they deliver the voice of the God. It is such a voice that judge events, covenant, war, disaster, idolatry, promiscuity, debauchery, injustice and etc. Prophets predicted the punishment, educated people, persuaded people to repentance and announced the eternal victory over darkness and death". [4]1 Therefore, prophets also is called "master" in Old Testament (Kings II 2:5/16), because they deliver God's wills, teach laws and educate people.

After the Ezra period, the scribe class rose and acted as mentor of people in place of prophet. In Hebrew, scribe has the meaning of "counting", with no particular religious meaning. They had the ability of reading and writing, and often were invited to transcribe law documents, military archives, administrative documents and personal letters. Gradually the scribe class took shape and they became court reporters, royal advisers and financial supervisors. They also supervised and managed temple affairs together with priests. After the establishment of the Second Temple, they became scholars and professional teachers to interpret laws. They did 
their utmost to maintain religious tradition and explained laws according to actual needs, guided people's lives with the laws. In fact, the scribe is the generic term of copier, lawyer and translator. They became the Hebrew's first generation of teachers. They did not live in country but went to city to educate people to obey the Lord, which was the duty of scribe and priest". [5]38-39 Ezra was "a ready scribe of the words of the commandments of the LORD, and of his statutes to Israel" (Ezra 7: 6/11/21). After the exile, the Jewish started to set up synagogue in order to maintain national and traditional tradition. Gradually the synagogue become to act as primary school in modern sense, meanwhile teacher as a profession is officially born.

\section{THE EDUCATIONAL SUBJECTS AND CONTENTS OF ANCIENT JEWISH PEOPLE}

Ancient Jewish society is male-dominated, so the focus of education is male. The boys shall receive elementary education from parents in which the religious education is the most important. In this way, the religious tradition of Jewish people is passed down from generation to generation. Old Testament clearly stipulates that father shall take the duty to educate their son and grandson about traditional religion and explain the meaning of the religious rites and God's commandments (Exodus 10:2). At this point, the boys shall learn moral principles from mothers. In addition to religious knowledge, boys also learn certain living skills from father. It is father's responsibility to teach their sons a skill that always are what they work on. A Jewish proverb says "your son will be a thief if you let him", which reflects the importance of father's this task. As school appears, Jewish people send their sons to school when they are weaned about three years old. They first learn to read and write 22 Hebrew letters and then learn to read and write a complete sentence. Then they start to learn measurement and math, drawing, music and etc., which is equivalent to primary education. As view of music education, Hebrew is treated as the most excellent musicians and singers in ancient Near East. When they went out of Egypt, Moses make a song to educate Israelites to bear it in mind that Yahweh lead them and redeemed them out of the slavery land (Exodus 15: 1 18). Prophetess Miriam also organized a women chorus to celebrate God's marvelous deliverance of the people at the Red Sea (Exodus 15:21). David was a famous harpist. When he was young, he played harp to divert Saul from boredom. Afterwards, he ever made a mournful song to lament the death of Saul and Jonathan. His songs are passed down from generation to generation. Nowadays, archaeologists have found a clay tablet in Ugaritic, recording a ballad and hymn, probably a Ganaan literature in the 1800 before the birth of Jesus Christ, which is called as "the oldest music in the word". After this, the would-be scribes shall follow scribes for further study and attend the secondary school to continue their studies. If children of the nobility want to be officers, they shall attend the royal school to learn Israelite laws, geographical and historical knowledge, as well as a diplomatic language, such as Aramaic (Kings II 18:26). At that time, "all magistrates have to receive the learning of Aramaic. Hebrew is mainly used in religious rites in
Jerusalem Temple as well as in schools as a classical language to teach national literature".[1]309

Hebrew nation is a suffering nation. Their national history is basically a history of warfare. Given by this specific situation, Hebrew men usually have to receive some special training. Military training or learning is the preferred course. Old Testament also clearly documented (Judges 3:2) Jewish boys should follow their father or brother to experience war on the battlefield. In addition, they also received the training on playing slingshot, bow, sword and spear. For example, the men of Benjamin Tribe were famous for playing sword and slingshot with double hand. Other tribes mainly were trained to use bow and arrow (Samuel 20: 22 22).

Since ancient Jewish society was male-dominated, women's education was inferior to that of men. Education plays a decisive role in the Jewish society, so girls still could get education opportunity. In a family, mother mainly is responsible to teach daughters, so as to make a tender and successful homemaking woman out of a girl. For girls, they first shall learn cooking, spinning, weaving and caring for children and managing servants. They also learn to care for livestock and manage vineyards. Sometimes, they have to learn milling grain and assisting their families to harvest their crops. In addition, girls may receive certain training in order to engage in certain occupations, such as nurses and midwife, mourners, singers or witches. Even prostitute was also a profession that a girl could choose at that time. In addition, girls shall learn reading and writing, so that they may read the laws and fear God. Girls were also required to learn knowledge about their religion and rites. In general, girls learned the knowledge at home and seldom in society. But there were some exceptions, the wives and daughters of the royal family and upper class were likely to enter some school to receive education. For example, mother of Lemuel has been a well educated woman. It can be said she was a talented teacher and took the main responsibility to teach Lemuel (Proverbs 31).

\section{TEACHING METHODS AND CHARACTERISTICS OF THE ANCIENT JEWISH PEOPLE}

In Jewish society, the first method they used to teach children is the oral repetition and stress memory. "The verb of Hebrew word sana (repeat) has the meaning of both 'teach' and 'learn"”. [2]401 "Children start to learn memorizing things once they start speaking. They would try to recite the full text without missing one word". [6]759 By oral repetition, their memory is enhanced. Deuteronomy $(6: 6 \sim 7)$ clearly stipulates to educate children to repeat the scriptures and bear God's teaching in mind. To facilitate children for learning and memorizing, Jewish people also use other good memory methods, such as the number method and the acrostic poem. Sometimes, "teacher may select one scripture for each boy which starts from the first letter of their name and ends with the last letter of their name. Once the student can recite it, he can get a volume, saying 'Hear, O Israel: The LORD our God, the LORD is one' (Deuteronomy 6:4)". [6]759 Oral teaching is an important method in the early Jewish education as well as for passing 
down of Jewish classics, even forming an oral teaching of law tradition.

Corporal punishment or flogging is also an important way to ancient Jewish education for children. As long as the child can not learn lessons, a father or teacher has the right to punish him, which is the responsibility of the father or teacher. Proverbs (23: 13 14) clearly stated: "Do not withhold discipline a child; if you beat him with the rod, he will not die; you beat him with a rod, and shall deliver his soul from hell". In particular, a father shall be responsible for his son's actions, because "the rod of correction imparts wisdom, but a child left to himself disgraces his mother" (Proverbs 29:15). Accordingly, Deuteronomy clearly provides that a child refusing to be disciplined by parents shall receive punishment. In this stick parenting, Jewish children often recite scriptures without mistaking a single word. This strict discipline has its significance to some extent, but in general, it is still a low-level education approach.

Jewish education is closely associated with national religion. Its original purpose is to teach children to know, serve and fear God and teach them to be a holy person. With the development of society and nation, they add some worldly contents into children education, such as moral principles, the history of the people's suffering and living skills and others. Jewish nation is a unique nation. The history of the nation is full of mysterious legends. In the suffering and displaced national history, "Jewish people know Mosaic Law and their history" through education. Under oppression of foreign powers, they still maintain their national dignity and until modern times, they have restored their state". [6]757

\section{REFERENCES}

[1] D.N.Freedman ed. Anchou Bible Dictionary. 6 vols. New York: Doubleday, 1992.

[2] Wu Luoyu editor. New Bible Dictionary. Translated by China Graduate School of Theology. (Hong Kong) Tiandao Shulou Co., Ltd., 1996.

[3] Zhao Ning: Prophets - Interpretation of Apocalyptic Literature. Beijing: Religious Culture Press, 2004.

[4] Chouraqui. Jewish History. Translated by Wu Moxin. Beijing: Commercial Press, 2001.

[5] S - E - Frost. Historical and Philosophical Foundation of Western Education. Translated by Wu Yuanxun. Huaxia Publishing House, 1987.

[6] Chen Huirong editor. Lion Handbook to the Bible (three volumes). (Hong Kong) Christian Communications Ltd., 2001. 